\title{
Socialno delo z uporabniki Območnega združenja Rdečega križa Novo mesto v času razglašene epidemije covida-19
}

Sem univerzitetna diplomirana socialna delavka, zaposlena kot strokovna sodelavka na Območnem združenju Rdečega križa Slovenije Novo mesto. Gre za samostojno, nevladno, humanitarno, nepridobitno in prostovoljno organizacijo, ki pomaga pri preprečevanju in lajšanju trpljenja ljudi, pri zaščiti življenja in zdravja, krepitvi gibanja za zdravo življenje in zagotavljanju spoštovanja človekovih pravic, še posebej med oboroženimi spopadi in drugimi izrednimi stanji. ${ }^{1}$ Naša najpomembnejša dejavnost je pravočasno in učinkovito zagotoviti pomoč vsakemu, ki se znajde $\mathrm{v}$ stiski.

Marca 2020 je bila v Sloveniji razglašena epidemija covida-19. V nadaljevanju predstavljam, kako se je naše združenje prilagodilo in odzvalo na nove (izredne) razmere.

Na lokalni ravni ves čas aktivno sodelujemo z izpostavo Uprave RS za zaščito in reševanje Novo mesto, z Mestno občino Novo mesto in z vsemi drugimi sedmimi občinami, ki jih naše združenje s svojim delovanjem pokriva. Čeprav smo na Rdečem križu kriznih razmer vajeni, smo bili pri delu še pazljivejši, saj bi bilo lahko zaradi covida-19 ogroženo naše zdravje, zdravje naših domačih in zdravje uporabnikov. Zato smo se morali na strokovno delo pripraviti in se zanj dodatno usposobiti. Vsi zaposleni smo se ob začetku prvega vala epidemije udeležili usposabljanja na področju epidemije infekcijskih bolezni. Seznanili smo se z možnostjo cepljenja in pomenom upoštevanja pravil pri uporabi zaščitne opreme (zaščitne maske, rokavice, razkuževanje, prezračevanja prostorov ipd.). Seznanili smo se tudi z navodili Nacionalnega inštituta za javno zdravje glede preventive pri širjenju koronavirusa in z navodili Rdečega križa Slovenije za delo z uporabniki pri delitvi pomoči.

Od 13. marca 2020 do 31. decembra 2021 imamo za pomoč uporabnikom pri spoprijemanju z epidemijo odobren projekt Evropskih socialnih skladov ReCovid - Pomoč ranljivim za boljše vključevanje v času COVID-19. Projekt je namenjen podpori ranljivim skupinam, kot so stari ljudje, brezposelni, ljudje na robu revščine in druge osebe, ki doživljajo visoko stopnjo socialne izključenosti. Namena projekta sta pomoč najranljivejšim skupinam prebivalcev zaradi epidemije covida-19 in zmanjševanje njenih posledic.

Pri delu smo se strokovne delavke združenja zaradi epidemije srečevale $\mathrm{z}$ različnimi novimi izzivi. $\mathrm{V}$ nadaljevanju jih naštejem in opišem, kako smo se odzvali nanje.

1 Več o nas v: Območno združenje Rdečega križa Slovenije Novo mesto (2021). 
- Organizacija (lastnega) dela. Zaposleni smo se udeležili sestanka o razdelitvi delovnih nalog od doma. Delovanje smo prilagodili razmeram tako, da je v prostorih Rdečega križa potekalo zgolj dežurstvo, večina dela pa je potekala od doma - tako smo lahko še vedno zagotavljali informacije, psihosocialno podporo ipd. in opravljali drugo delo po telefonu in e-pošti. Seje komisije so potekale dopisno, tako da smo finančne pomoči delili redno. Imeli smo veliko telefonskih stikov s krajevnimi organizacijami, ki so sporočale o potrebah ljudi in se nanje tudi same odzivale. Vsak dan smo poročali štabu Civilne zaščite in Rdečemu križu Slovenije o izvedenih aktivnostih. Skrbeli smo za obveščanje javnosti z objavami na spletni strani našega združenja in v lokalnih medijih.

- Pomanjkanje opreme. Aprila in maja 2020 nam je primanjkovalo mask, zato smo se razveselili donacije zaščitnih mask. Pridne prostovoljke so šivale, pakirale in razdeljevale zaščitne maske $v$ poštne nabiralnike uporabnikov.

- Povečanje potreb po psihosocialni pomoči. Opažamo povečanje potreb po psihosocialni pomoči. Povezane so tudi s tem, da so se ljudje v novih razmerah znašli v stiski tudi zaradi zmanjšanja dohodkov in celo odpovedi delovnega razmerja, ker podjetja niso imela dela. Opažamo, da je bil pogosto ljudem v tolažbo že sam pogovor s socialno delavko, ki jih je poslušala.

Hvala, ker ste me poslušali. (Izjava uporabnice)

Psihosocialna pomoč/podpora poteka v obliki informiranja, svetovanja, pogovorov in pomoči pri uveljavljanju socialnovarstvenih in drugih pravic. Izvajamo jo $\mathrm{z}$ individualnim svetovanjem in pogovori znotraj terenskega dela. Z namenom informiranja, svetovanja in zagotavljanja razbremenilnih pogovorov izvajamo telefonsko svetovanje, za uporabnike smo vzpostavili tudi telefonsko družabništvo. V pogovorih z ljudmi opažamo povečano število prosilcev pomoči, ki so uveljavljali pravice iz javnih sredstev (denarna socialna pomoč, varstveni dodatek), prosilcev za materialno pomoč, večje potrebe po hrani, višje stroške uporabnikov (otroci in odrasli ostajajo doma) in več osebnih stisk. Stiske smo pomagali reševati z različnimi dejavnostmi. Uporabnikom po potrebi pomagamo tudi pri prijavi in spremstvu na cepljenje proti covidu-19.

Prav tako pomagamo pri urejanju socialnovarstvenih pravic, kot so urejanje denarne socialne pomoči, varstvenega dodatka in druge socialne pomoči, ki posamezniku omogoča dostojno življenje.

- Povečanje potreb po prostovoljcih in po pomoči ranljivim skupinam prebivalstva. Občine so se odzivale proaktivno in na podlagi pobud so se občani aktivirali za sosedsko pomoč. Objavili smo potrebo po vključevanju novih prostovoljcev. $\mathrm{V}$ tem času se nam je javilo 40 novih prostovoljcev, ki so bili pripravljeni razvažati hrano in poskrbeti za ranljive skupine ljudi. Aktivirali smo prostovoljce za merjenje telesne temperature zaposlenih $\mathrm{v}$ podjetjih ter za druženje in vzpostavljanje stikov s svojci uporabnikom $v$ domovih za stare ljudi.

- Povečano število ljudi brez doma. Na Območnem združenju Rdečega križa Slovenije Novo mesto izvajamo tudi javno verificiran socialnovarstveni program 
Delo z brezdomnimi in socialno ranljivimi za boljše vključevanje, ki ga v času od 2021 do 2027 sofinancira Ministrstvo za delo, družino, socialne zadeve in enake možnosti. V program vključujemo socialno ranljive skupine: brezdomne osebe, osebe z invalidnostjo, stare ljudi, enostarševske družine, tujce, osebe $s$ težavami zaradi odvisnosti, mlade brezposelne ljudi, osebe po prestajanju zaporne kazni, Rome in druge socialno izključene osebe. Opažamo, da se je število brezdomnih ljudi v času epidemije povečalo oz. je epidemija povečala njihovo vidnost. Imamo večljudi (ki so se pred epidemijo »potikali naokrog«), ki živijo v tako slabih stanovanjskih razmerah, da niso primerne za življenje (brez vode, elektrike, objekti se podirajo). Med razglašeno epidemijo smo imeli tudi težave $\mathrm{z}$ iskanjem ustrezne namestitve za brezdomne osebe.

- Povečanje potreb po t. i. kriznih namestitvah. V času epidemije covida-19 smo zaznali potrebo po omogočanju kriznih namestitev, zato to možnost omogočamo v garsonjeri Rdečega križa. Krizna namestitev je namenjena tistim, ki zaradi različnih razlogov potrebujejo začasno namestitev. Garsonjera omogoča samoizolacijo zaradi covida-19, ki si jo osebe zaradi šibke socialne mreže težko privoščijo. Krizno namestitev v garsonjeri Rdečega križa smo doslej (julij 2021) zagotovili eni osebi, ki je prišla iz tujine in je morala biti v karanteni. Na nas sta se obrnili še dve ženski, ki sta zaradi ločitve iskali začasno namestitev, vendar sta na koncu rešili situacijo tako, da se nista namestili v naše prostore. Tudi v prihodnje bomo zagotavljali to možnost. Pri nas je možno tudi vzdrževanje osebne higiene, še posebej dobrodošlo za tiste, ki doma nimajo kopalnice oziroma pralnega stroja. To možnosti je izkoristilo sedem oseb.

- Izzivi pri razdeljevanju hrane. Hrano smo zaradi covida-19 začeli pripravljati v pakete in smo jih uporabnikom razdelili brez neposrednih telesnih stikov. Razdeljevanje živilskih paketov smo izvajali po vnaprej določenih terminih uporabnikov, razdeljevanje donirane hrane pa je potekalo ves čas neprekinjeno na domovih uporabnikov ali na vnaprej dogovorjenih prevzemnih mestih. Sprejemali smo telefonske klice in dostavljali živilske pakete tudi na domove uporabnikov v samoizolaciji in karanteni. Dostavljali smo zdravila iz lekarne in opravljali nakupe za uporabnike. Uvedli smo dodatno razdelitev izrednih živilskih paketov z daljšim rokom uporabe. Za razdelilnico hrane, ki je namenjena brezdomnim uporabnikom, smo nabavili zaščitne pregrade iz pleksistekla. Uporabniki si redno razkužujejo roke in pred vsakim vstopom $v$ razdelilnico hrane prejmejo zaščitno masko za enkratno uporabo, prostore pa tudi redno zračimo.

- Izzivi starih ljudi. Stari ljudje so bili v času epidemije covida-19 ena najranljivejših skupin prebivalstva. Srečevali so se predvsem s problemom mobilnosti (ukinjanje javnega prometa, zapiranje občin/regij) ali slabe povezave z javnim prevozom. Zaradi izolacije so (bili) stari ljudje in socialno izključene osebe osamljeni in manjka jim socialnih stikov. Zaradi večje ranljivosti in večjega zdravstvenega tveganja si pogosto tudi niso upali oziroma si ne upajo iz hiše ali stanovanja. Veliko jih živi samih, brez svojcev in s pomanjkljivo socialno mrežo. $V$ času epidemije je postala ta problematika še večja. Zaznavamo povečanje števila prosilcev za materialno pomoč, več potreb po hrani ipd. 
Kruha si ne morem speči, sadje in zelenjava sta zame predraga. Včasih prosim vnukinjo, da gre zame v trgovino, ampak pravijo po televiziji, da ni dobro hoditi v trgovino in naokoli. Zato sem zelo hvaležna Rdečemu križu za hrano. Mi zdaj še posebej veliko pomeni. (Izjava uporabnice)

- Izzivi družin. Veliko družin je v času epidemije prosilo za pomoč pri plačilu položnic za najnujnejše življenjske stroške (voda, elektrika, ogrevanje) ali pakete s hrano. V zimskih mesecih smo opažali tudi povečanje potreb po odejah in toplejših oblačilih, predvsem za otroke.

Mož je v tej situaciji ostal brez službe, jaz brez strank. Naročil ni, ostanejo še dolgovi in odprti računi. Imava dva šoloobvezna otroka. Pomagam jima za šolo, kolikor znam. Težko je, ker je pri hiši samo en računalnik. Če je možno, bi prosili, da nam pomagate pri plačilu računov za vodo in elektriko v tej hudi situaciji, ki je velika preizkušnja za vso našo družino.

(Izjava uporabnice)

Na nas so se obračali starši in šolske svetovalne delavke in povpraševale, ali imamo na voljo računalnike z opremo za pomoč pri delu na daljavo. Tako smo otrokom pomagali z nakupom računalniške opreme. Prejeli smo donacije tabličnih računalnikov in jih razdelili družinam s slabšim socialno-ekonomskim statusom za pomoč pri šolskem delu na daljavo. S pomočjo zbranih donacij smo nakupili tudi nekaj prenosnih računalnikov in jih razdelili učencem za pomoč pri šolskem delu na daljavo.

- Izzivi pri izvajanju terenskega dela. $\mathrm{V}$ času epidemije se nam zdi izjemno pomembno tudi terensko delo, saj so naši uporabniki pogrešali socialne stike. Pri terenskem delu smo v času covida-19 opažali predvsem strah pred okužbo, zaradi večje osamljenosti in zaprtosti vase pa tudi povečano število ljudi, ki imajo težave z duševnim zdravjem oziroma zasvojenostjo. Število obiskov na domu je bilo leta 2020 1187, do konca julija 2021 pa že 933.

Na Območnem združenju Rdečega križa Slovenije Novo mesto delo kljub epidemiji opravljamo $\mathrm{v}$ različnih oblikah (tudi v obliki neposrednega stika z ljudmi, seveda ob upoštevanju vseh potrebnih zaščitnih ukrepov), ponujamo različne storitve in programe ter se $\mathrm{z}$ oblikovanjem novih odzivamo na zaznane potrebe.

\section{Izzivi, ki ostajajo in načrti za prihodnost}

Kot je razvidno iz opisanega, je covid-19 povzročil veliko prilagajanja pri izvajanju naših aktivnostih pa tudi odpoved nekaterih že načrtovanih dejavnosti. Ena takih je bila akcija urejanja okolice hiš, a je potem nismo mogli izpeljati zaradi zaprtja države. Ne moremo tudi izvajati vseh dejavnosti na Rdečem križu, ker so v nekatere vključeni stari ljudje oziroma kronično bolne osebe, ki so še posebej rizična skupina. Za lažje premagovanje izolacije in osamljenosti sta se dodatno razvili prostovoljsko delo za pomoč starejšim in socialno ogroženim ter telefonsko družabništvo. Obe dejavnosti želimo ohraniti in dodatno razvijati. Pokazalo se je, da so prostovoljci po krajevnih organizacijah pomemben vir informacij za ljudi, ki iščejo pomoč oz. oskrbo s hrano, drugimi potrebščinami ali spodbudno besedo, ki je bila v teh razmerah zelo potrebna in dragocena. 
V prihodnje bi radi med prostovoljci ohranili obstoječe in pridobili še več mlajših, ki bi pomagali pri naših akcijah. Zaradi posledic epidemije na različnih področjih, ki bodo opazne šele v prihodnosti, namreč pričakujemo, da se bo povečalo tudi število prosilcev pomoči. Zato smo se odločili za akcijo zbiranja sredstev v Sklad za pomoč ljudem v stiski. Z zbranim denarjem bomo plačali najnujnejše življenjske stroške družinam v stiski, pomagali pri nakupu šolskih potrebščin šoloobveznim otrokom, zagotavljali tople obroke brezdomnim osebam.

Opažamo, da še posebej stari ljudje potrebujejo več socialno-zdravstvene oskrbe (reden stik, pomoč pri gospodinjskih opravilih, pomoč pri zagotavljanju socialno-zdravstvenih pravic), prav tako pa se pri delu pogosto srečujemo s socialno izključenostjo naših uporabnikov, visoka je tudi stopnja tveganja revščine.

Med epidemijo sem spoznala, da sta zelo pomembna dobro sodelovanje in konstruktivna komunikacija, da znamo stopiti skupaj in si pomagati. Neprecenljivi sta solidarnost in sosedska pomoč. Vsi skupaj smo se iz pridobljenih izkušenj veliko naučili. Za prihodnost si želim, da bi bili še pozornejši na stiske ljudi in bi si znali pomagati.

\section{Maja Gorenc Šulc}

\section{Vir}

Območno združenje Rdečega križa Slovenije Novo mesto (2021). Pridobljeno 25. 8. 2021 s http://novomesto.ozrk.si/o_nas/ 
